\title{
The Methodology of the Islamic Behavioral Sciences
}

\author{
Mahmoud Abu-Saud
}

Methodology is the means of formulating the principles that determine the guidelines for various sciences. Or, in other words, it is the system of practices and procedures that, when applied to a specific branch of knowledge, will result in furthering the particulars of that knowledge. The concept of studying methodology is not new. In fact, some trace it back to Plato and Aristotle, who gave it special consideration. Its study has developed to such an extent that it has now become a science in and of itself under the formal title of "methodology." Its content has also become intertwined with the philosophy of the sciences themselves.

\section{Methodology in the West}

We can say with certainty that the ideological and civilizational development that affected the West throughout history left profound traces on the essence of methodology. The domination of the Catholic church and its representatives over the methods of scientific research placed limits on rational thinking and confined it within the strictures of church doctrine on the concepts and principles that explained nature and human behavior.

In those centuries, man was not the master of the universe. Furthermore, human thought not only depended upon religious teachings but was actually subject to it. Knowledge was in no way dependent on the soundness of methodology. On the contrary; it was measured by God's pleasure and acceptance, since He was understood to provide knowledge and reason with legitimacy. Of course it was the church which, throughout this period, actually expressed divine pleasure and acceptance on behalf of God. In this manner, the church became the only source for the discovery of nature's secrets, and Christian dogma became the only criteria for distinguishing between scientific fact and fiction.

The late Mahmoud Abu-Saud served as an academic advisor to the International Institute of Islamic Thought (IIIT), Herndon, Virginia, and as a referee for the American Journal of Islamic Social Sciences (AJISS). During his lifetime, he taught at several universities and contributed towards the development of Islamic economics. He passed away in London on 24 April 1993. 
Subsequent to the Renaissance in the second half of the fifteenth century, however, an ideological revolution took place, freeing Europe of the religious shackles restraining reason and experimentation.

Yet this liberation proceeded slowly, despite the burgeoning independence of scientific inquiry in the seventeenth and eighteenth centuries, for European scientists continued to be influenced by the last vestiges of church authority. As evidence of this we may note that Descartes, one of the first to call for the separation of mind and matter, concluded that the scientific method could not be relied upon unless approved by God. We can also see that this religious tendency was prevalent in the works of Newton and Lebnitz.

A more radical reaction emerged to this historic event, one that affected the methods, philosophies, and ideas prevalent in the nineteenth and twentieth centuries. Philosophers and scientists were so impressed by the success of Descartes' experimental method that they immersed themselves in it and followed it almost exclusively. But eventually, they became more moderate in its application, and some actually rejected it or at least considered it less than ideal for every scientific situation.

Thus the methodology of Kant, which incorporated the experimental method with "tangible idealism," began to develop. This was followed by Eddington's methodology of "the relativity of mass." Recently, we have begun to read in the works of such contemporary philosophers as Fromm, Capra, and Sourkin of a new opinion that sees no escape for methodology from the consideration of revelation as a source of knowledge, along with reason and experimentation.

At the same time, this methodology started to shy away from using the traditional analytic approach, which concludes that knowledge of characteristics and behavior cannot be achieved except through studying the integral parts of the whole. It also decided that this "whole" must be an influencing factor on the characteristics of the part in both the study of matter and behavior. This is the most important feature of the contemporary methodology: matter is studied as a mass that cannot be partitioned from energy and, likewise, humanity must be studied as an integral unit consisting of matter, reason, and spirit, a unit in which no single aspect can be separated from the other two.

\section{Islamic Methodology}

Since its inception, Islamic methodology has followed a very different path from that of western methodology. Islamic methodology began in a fully liberal scientific atmosphere that was distinct from Aristotle's positivism and void of the church's mandate. Reflection was free of any con- 
straints, with the exception of certain general principles or self-evident axioms that are indispensable to logical thought. Many of these axioms are taken from the teachings and directives of the Qur'an. Accordingly, Islamic thought began unhindered by religious or clerical restrictions that would have prevented it from understanding the secrets of nature, discovering the laws of its motion, and studying the conduct and behavior of human beings in society. In fact, Islam urged individuals to reflect upon the universe and uncover its secrets. It also included the main elements upon which Islamic methodology is based.

This methodology developed into a formal science during the second hijri century. It was not inspired by a struggle for the freedom of thought, but by the requirements of a fast-growing scientific renaissance and a strong desire to acquire additional knowledge. Islamic methodology adopted the Qur'anic approach of reflection and contemplation. Indeed, law derived from the Qur'an was based on the jurists' understanding of both underlying reasons and circumstantial contexts. The example of the Prophet, moreover, opened the way for researchers, allowing ijtihad (creative self-exertion to derive laws from legitimate sources) and assigning rewards to those who undertook it, regardless of whether or not their conclusions were correct.

It was natural that the science of $u s \bar{u} l$ or Islamic methodology should consider the Qur'an, the Sunnah, and ijtihad to be legitimate sources of tashri (the formation and application of religious law). This is because methodology, by definition, is a means and not an end. However, the means must be related to the end, otherwise the former would not lead to the latter. The implication here is that as long as the concept of knowledge is associated by Muslims with faith and with the Shari'ah, it is inevitable that the path of knowledge for a Muslim will be subject to these and to all that is associated with them.

In order to prove this, it is enough to say that western methodology always followed the prevalent scientific method in every stage of its civilization. Methodology was Catholic during the Middle Ages, Cartesian after the Renaissance, and liberal and Marxist during the present era. Inasmuch as humanity changes its ideals, it changes its methodologies as well. So, in reality, ideals are what shape the objectives of "science" in its various forms. For that reason, Cartesian methodology, and the methodologies that followed it, became the means that led to the understanding of the sciences of nature and human behavior. These constituted the entire "science" with which westemers were preoccupied in order to achieve the utmost satisfaction of their materialistic needs: the largest portion of material power, the greatest material luxury, and the maximum possible fulfillment of sensual desires. There is no doubt that the current metho- 
dology would change if the ideals of the time changed and the optimum purpose of life became other than "material and tangible" - something higher and more eternal, something that is inclusive of material while controlling it.

As the goal of the Muslim is the worship of God and the implementation of His Shari'ah, it follows that Islamic methodology must be the collective precepts that regulate the means and research leading to the knowledge of all Shari'ah laws relevant to social conduct and activity in society. We may describe this methodology as constituting principles derived from the Islamic ideal, or what we call shirah-principles that determine the subject of every behavioral science, the kind of regulations that control it, and the structure that must be available to build its disciplinary framework.

From this comprehensive description, we see that we must know the ideals that determine a Muslim's goals and that we must extract, from within the parameters of these ideals, the general theory of the science to be discussed. Finally, we must invent the means required for applying the specific scientific theory. To reach these goals, we need to use scientific methods, which, collectively, are known as Islamic methodology.

Historically, Islamic methodology, or the science of usül al fiqh, remained dynamic and vital from its inception during the Umayyad period until the end of the Golden Age in al Andalūs (Muslim Spain), for methodology advanced alongside civilization. In Baghdad, Muslims produced qiyās mursal (analogy) and, in al Andalūs, istiqrä' (induction) and istinbāt (deduction) were discussed. Muslim thinkers were not preoccupied by the Cartesian partial outlook, because figh comprised both 'ibâdāt (religious rituals concerning an individual's relationship with God) and mu 'ämalāt (transactional disciplines concerning an individual's relationship with society). In fact, scholars of religion consider certain material transactions to be among the pillars of Islam. Ibn Sīnā, Ibn Rushd, and other Muslim scholars were able to incorporate Greek philosophy into their own Shari'ah-based theories. Consequently, they created their own methodology, which was developed largely at Cordoba.

However, by the eighth hijri century, as the Muslim community changed its ideal to one of material enjoyment and began to abandon such necessary constituents of civilization as acquiring knowledge and upholding moral values, Islamic methodology began to stagnate.

\section{Science vs. Methodology}

The behavioral, social, and human sciences are those sciences that study, from every angle, humanity and human interaction in society. Their 
subject is the exploration of individuals' motives and the consequences of their actions. This term is usually given to such sciences as sociology, anthropology, psychology, behavioral biology, economics, political science, geography, history, and law.

Until 1950, these sciences were called "social sciences." Later on, the term "behavioral sciences" spread among American writers. Some of them distinguished between the two by indicating that "behavioral" implied the experimental method to a greater extent than "social." Behavioral science also studied the relationship between these sciences. It is fair to say that this distinction is arbitrary, for there is no reason to prevent the use of the experimental method or discussing relations between these sciences under the term of "social" science.

At any rate, there is no disagreement that human beings are naturally motivated to acquire knowledge, regardless of whether or not they are Muslims. What is important is the objective sought by the individual and society through the use of the science. This is because, generally speaking, knowledge-or knowing the truth by means of the evidence-can only be defined in social terms by how it reflects on humanity (whether favorably or unfavorably). The reference for this objective is the ideal that prevails in the society. As we mentioned earlier, the aim of the western ideal is material satisfaction in every aspect of life: satisfying the desire for material domination by using material force, satisfying the desire for material ownership by increasing material luxury, and satisfying the desire for all types of sensual pleasure and experience.

The objective of acquiring knowledge in the Islamic ideal is to serve the interests of humanity within the parameters of the Shari'ah. This aim helps human beings to transcend their lives as mere individuals so that their relations with others are of optimum benefit to themselves and to society. This will be achieved only when the motive of every action is to draw nearer to God, to seek His pleasure and avoid His anger, to struggle to reach $\mathrm{Him}$, and to seek enlightenment through $\mathrm{Him}$, since $\mathrm{He}$, the $\mathrm{Re}$ vered and Exalted, is the Eternal and Absolute Creator; He who owns everything and to whom everything reverts; He who governs every being and possesses all knowledge. Thus Islamic methodology has a special characteristic, not because Islam defines science differently from the way that others define it (truth is absolute), but because the objective of a Muslim's search for knowledge is different from that of a non-Muslim. For this reason, the methodology has evolved in a different manner.

Methodology is the approach that allows one to arrive at science and the path leading to it. Likewise, science is the path to happiness in this life and the hereafter: material luxury, or what previous scholars have called procuring the interests of humanity in order to draw nearer to God. 


\section{Two Kinds of Methodology}

One kind of methodology deals with the tools of methodological research, its aspects and approaches, i.e., istinbät, istiqrā', qiyās, and the statistical analysis of phenomena. This methodology treats human behavior as subject to fixed laws similar to those of mathematics and chemistry, or subject to structural or functional research. It is general in nature and is not characterized by values, meaning that it can be applied to any methodology and does not need to be related to any school of thought or theology, for istinbāt, istiqrā', qiyās, the laws of probabilities, and similar tools of research were used by scholars of various theological persuasions without differentiation or qualification.

The other type of methodology, in terms of its subject and goal, is associated with science itself. The methodology of physics and mathematics, for example, differ from that of the behavioral sciences and humanities by virtue of the differences between living and inanimate matter. Moreover, the objective of science in a society that views the human being as the center of existence and does not believe in God and spiritual values is essentially different from the methodology of a science that has, as its purpose, belief in God as well as worshipping and praising Him. The latter looks toward the eternal truths uncovered by science, recognizes divine revelation-which transcends reason-as a source of knowledge, and acknowledges the eternal values inherent in God's unity.

We will not with the first type of the methodology, which is related to the tools of research and is easy to comprehend. Instead, we will discuss the second type, where we can distinguish the purpose of science by comparing Islam with other ideologies. We can do this because the socalled Islamic behavioral sciences must necessarily have their origins in Islamic precepts (tashri $)$ in the sense that their principles and laws must either be in accord with or, at least, not be in violation of the Shari'ah.

If the Shari'ah as a whole is considered by Muslims to be true, if all of it is good, and if its purpose is to ensure the interests of humanity, then it is impossible for science to disagree with it. This claim can be made based on the following assertion: the purpose of behavioral science is the same as what that of the Shari'ah-the interests and happiness of human beings - although the concept of interests and happiness are as different as the schools of theology or thought.

\section{Methodology and the Science of Usül al Fiqh}

It is accepted that the behavioral sciences deal primarily with the study of human beings' behavior and their relationship with other mem- 
bers of society. To say that these sciences are theoretical is greatly exaggerated, for they are certainly not abstract or unrelated to what is tangible. It is closer to the truth to say that the behavioral sciences study the activities of individuals that relate to tangible matter, and that they formulate the principles and axioms in the form of laws (i.e., constant relationships between variables) governing this behavior and interaction.

If this scientific concept is examined closely, it will be found to be quite similar to the concept of fiqh al mu'ämalāt, which has been propounded time and again by Muslim scholars since the second hijri century. The classical scholars of Islam defined fiqh as "the knowledge of practical Shari'ah laws derived from the particulars of supporting evidence." The important elements of this definition are: a) that fiqh is an acquired science, which means, in the words of al Ghazāin, that it is the knowledge of truth through its manifestation; b) that the supporting evidence for any legal decision is taken from the Shari'ah; and c) that the laws deal primarily with what is "practical," (i.e., they do not deal with imaginary situations or abstractions).

In addition, they divided fiqh into two basic kinds: fiqh al 'ibādāt (the physical performance of those rituals that are obligatory to a Muslim's worship and determine the relationship between the believer and God) and fiqh al mu'ämalät (the part of fiqh that encompasses all kinds of social, political, economic, legal, moral, and other transactions.) Fiqh al mu 'âmalāt is actually the subject of the behavioral sciences. It does not deal, in its traditional form, with what jurists call "the evidence of general principles" or, in other words, general theories derived from the Shari 'ah. Rather, it is limited to "specific supporting evidence," that is, the particular evidence used for the formulation of a legal opinion in a specific case. The "evidence of general principles," however, falls within the parameters of ussul al fiqh, which is defined as knowledge of the principles and methods leading to the derivation of practical Shari'ah laws from the particulars of supporting evidence.

A jurist studies physical and verbal occurrences and then considers the known laws and rulings in order to decide which of them is applicable in a given situation. Thus a jurist applies established Shari ah interpretations to the deeds and words of people with the intent of formulating a legal opinion, defining rights and obligations, and specifying what is wäjib (obligatory), mustahab (commendable), $j a{ }^{\prime} i z$ (allowed), ghayr jā'iz (disallowed), and makrūh (reprehensible).

While fiqh al mu 'ammalät may be considered to be closely akin to the behavioral sciences, usül al fiqh is closest to methodology. In fact, it is probably Islamic methodology itself. This is borne out by the fact that when we study the science of Islamic sociology, Islamic economics, or 
any other Islamic behavioral science, our only intention is to study the relevant Shari'ah rules and laws in order to derive a legal decision on that part falling within the domain of the science to which it is related.

Yet civilizational development led us to a stage in which the concept of behavioral science differed from that given in the original fiqh al $m u$ 'āmalāt in many aspects. Modern behavioral science includes a general theory for this science. In general, modem scientists divide this theory into "substantive" and "normative" categories. The former is what jurists call the "practical legal decisions" that represent the status quo. The latter describes the decision in a normative light or, in other words, whether the decision is good or bad, pretty or ugly, virtuous or evil, in addition to many other normative adjectives.

It was recognized by western scientists that every event must have a predicate. Nevertheless, because it is impossible to "measure" a normative description, as this measurement differs from one person to another, and because the philosophy of science per se is based on a substantive ideal that has no room for normative values to appreciate the essence of its look at al mu'ämalāt, the normative side has been dropped from the study of behavioral sciences. It therefore became limited to what is empirical and can be sensed and measured.

This separation between substantive and normative descriptions in the behavioral sciences has no place in Islamic methodology. In fact, many modern western scientists concur in incorporating many of the methodological studies into the heart of behavioral science. Many gave all questions pertaining to the wisdom of a science the term "philosophy." Thus there is a philosophy various physical sciences (i.e., physics, chemistry, biology, mathematics, and astronomy) and of such humanities as political science, sociology, and economics. This philosophical study focused on the general theory of each science, gleaning from its ideal the defining theory that determines the relevant method of scientific research.

We are now at the stage where we have to decide if we should continue to consider fiqh al mu'ämalät and the science of usül al fiqh as inclusive of both the modern behavioral and methodological sciences. Should we recognize the necessity of developing them in accordance with present needs, or should we reconsider our own understanding as to the substance of the Islamic behavioral sciences so that we can include in each science the methodology needed to relate it to its subject? Should we limit ourselves to creating a comprehensive philosophy for the foundations of Islamic society in conformity with the guidelines of the Shari'ah and in accordance with the principles regulating relations between individuals, their rulers, and their political systems and between structured political societies, both Islamic and non-Islamic? 
Most contemporary researchers recommend maintaining and further developing the science of ușül a fiqh, while some view it as the only Islamic methodology. The most prominent of those who have considered this subject is Hasan al Turābi, who is the most daring intellectual in the field of development. I recall that Jamãl 'Ațiyah called for the reconsideration of this science many years ago, and that he was supported by Yūsuf al Qaradāwī. However, neither of these two contributed anything of significance to this sought-after renewal. I do not know any contemporary usüli scholar (i.e., methodologist) who has dealt with the subject in light of prevailing methodological thought on the modem behavioral sciences. In addition, I know of no one who has pointed out this subject's relationship to the science of $u s \underline{u} l$ al fiqh. The field of research is still wide open and void of researchers, despite the dire need for the development of methodological basics relevant to the spirit of our age. This is the situation, even though Muslim intellectuals often speak of the importance of this subject and the need for serious academic research regarding it.

In view of the absence of modern Islamic methodology, some specialists in the behavioral sciences have tried to develop their own particularized, Shari'ah-derived, methodology for application within their own disciplines. In doing so, they drew on what Muslim intellectuals of the classical age had written concerning the rules and principles of the usült sciences. For instance, in his exhaustive chapter on Islam, AbūSulaymān presented frank opinions on some of the questions that cause disagreement among the ușülìūn. We also find that Saleem Al-Awwa presents, briefly, the same subject in the introduction to his Regarding the Political System of the Islamic State. The jurist al Qaradāwī wrote about ijmā * (consensus), qiyās (analogy), tarjih (preponderance), and other topics related to the science of ușül in his Fiqh al Zakāh. I personally felt obligated to take up the science of $u s \bar{u} l$, discuss its principles, and allocate a special study to it in my The Fiqh of Contemporary Zakah.

It is essential for those studying Islamic behavioral sciences to consider the science of $u s \bar{u} l$ as a starting point. This is a prerequisite for all serious research, since these sciences are independent of western sciences by virtue of being derived from a completely different source: the Shari'ah. I admire what al Sanhūrī wrote in the introduction to his The Sources of Truth in Islamic Fiqh on the comparison of western humanmade laws and the legal decisions of fiqh. This is commendable and incontestable. However, to attempt to reconcile the difference between them is not completely favorable, for the originality of figh distinguishes it from other sciences and grants it sublimity of status and depth of wisdom.

I see no harm in developing fiqh by dividing it into several different behavioral sciences. After doing that, we can call the resulting sciences 
whatever we like: a fiqh of sociology, a fiqh of economics, a figh of politics and government, and fiqh of many other sciences and branches of knowledge. I do not hesitate to do this, provided that the development of this fiqh is preceded by a fundamental methodological development so that these different sciences will all follow one approach, yield to one logic, and lead to one aim-the establishment of the Shari 'ah as the guarantor of the interests of humanity.

\section{Basic Questions Affecting Development}

I am not an usüli scholar, so I cannot allow myself to indulge in this important science. Nonetheless, as I deal with the behavioral sciences through study and analysis, I find myself with no choice but to have recourse to this science in order to make a proper evaluation of my study. When reviewing the old ussüli principles, I find myself facing several obstacles. Sometimes I encounter the sort of ambiguity that leaves one in the dark, or a confusing surfeit of opinions that leave the researcher in a quandary as to which is more reliable or authentic. One also notes shortcomings that stem from the failure to develop this rich heritage in order to include such new methodological principles as the experimental method, relative consideration, the theory of totality, and other advanced methodological tools and theories.

If we take for granted that the new behavioral sciences must be derived from the Shari'ah and that the sources of the Shari'ah or its supporting evidences are contained only in the Qur'an, the Sunnah, ijma $\bar{a}^{*}$, and ijtihad (including qiyās, maslahah mursalah [issues of public interests with neutral morality and no legal precedent], shar ' $i$ legal practice, istish $\bar{a} b$ [decision by association], the shar ' [canonical law of Islam] of our former intellectuals, and the writ of the Prophet's Companions), there will be questions that contemporary usülīyun mustdeal with in view of the requirements of this age, in addition to other questions arising by virtue of scientific development. These questions must become an integral and properly placed part of the framework of an usüli methodology.

Firstly: There is what is called the "historicity of the event," which means the historic circumstances in which the event took place, circumstances that colored the special shar $i$ legal decision in regard to the event. It is clear that the Qur'anic verses concerning practical injunctions are very few, perhaps 260 out of a total six thousand. These verses were revealed in certain historical circumstances related to a particular social environment. This is true whether the form of the law is determined to be relative or absolute, and in full cognition of the fact that the words of God are themselves eternal and absolute. 
What makes it necessary to consider this factor is that the purpose of the Shari 'ah and its laws is to procure the interests of humanity. But these interests may vary over time and in different social environments. For instance, can we interpret a law of definite occurrence and definite circumstantial evidence (within its own history) in a way that differs from its obvious meaning within a different social environment and historical context? If we can, what are the guidelines for such an interpretation? In other words, can we consider the "historicity of the event" a cause or a condition that constantly determines whether the law is applicable or not?

This concept saves us from the intensive disagreement about abrogative and abrogated verses, because some of the laws were revealed over time. For example, a verse is revealed in the form of a message indicating that a certain action is harmful and reprehensible. Then another verse, which urges people to abandon this action, is revealed, and then a verse indicating a clear prohibition. This is not an abrogation of the law, in the sense that it neither partially nor totally nullifies or voids the applicability of a Shari'ah injunction by subsequent (revealed) legislation.

Secondly: The Sunnah is considered the second source for the fundamental bases of religious legislation, for it either confirms, through tibyan (clarification), tafsil (explanation of details), tafsir (interpretation), taq$y \bar{d}$ (limitation), or takhsisis (specification), what was previously revealed or establishes laws that were not mentioned in the Qur'an. There is no dispute that this type of text is legislative or that what is established from it is considered definitive. The implication here is that the transmitted accounts of what the Prophet said, did, or consented to represent what was revealed by God; it was not the Prophet's ijtihad or personal opinion. The problem that an usüli scholar often faces is one of historic investigation, because it is very difficult to ascertain whether or not the Sunnah has been revealed. Earlier Muslim scholars have left us a huge number of hadiths, the actual occurrence of which is not easily determined, not to mention the question of revelation. In addition, they did not try to investigate this legal aspect.

What makes this problem more complicated is the hadith's ambiguity concerning its occasion and cause. If we know that most of the disagreements among the Islamic schools of thought usually go back to the imams' views on the hadith's authenticity and interpretation, the degree of difficulty that an usüli scholar faces when using it as supporting evidence for legal decisions becomes clear.

This is not new. In fact, previous Muslim intellectuals viewed the Prophet's sayings or actions, by virtue of his human nature or his personal experience, as not constituting Islamic law. In other words, the way he walked or moved and his "worldly behavior such as trade, agriculture, 
military organization and maneuvering, prescribing a medicine for a particular illness, and so on do not constitute Islamic laws, because they do not stem from his message" ("Abd al Wahhāb Khallāf, 'Ilm Usūl al Fiqh). This may be very logical, but the method of determining the supporting evidence for what is legal or not is so strenuous that this logic is of little value during application. It is no secret that there is agreement about the legitimacy of many hadiths dealing with rituals and worldly affairs. Are they revealed by God or based on the Prophet's ijtihad? It is enough to point out at this juncture that the nisāb (minimum amount of property liable to payment) of zakah and some of its general principles are both ritual and 'ibädah. It is also sufficient to say that the dispute over the hadith dealing with interest, a financial transaction, is well known.

Thirdly: Muslim scholars disagree on the meaning of $i j m \bar{a}^{*}$ (consensus). Some limit it to the consensus of the Prophet's Companions during his lifetime, while others believe that it is the consensus of the jurists who lived after the Prophet. Some say it is the consensus of the ummah on any subject in any age.

May Allah bless Imām Mālik, who said, "He who claims ijmā' is a liar. It may well be that people did disagree on an issue, but that one (the one claiming $i j m \bar{a}^{\prime}$ ) may not know of or hear about it. Instead, one should say: 'I do not know of people having disagreed on the matter,' or, 'I have not heard about any disagreement on it.'" In fact, there has been a widespread acceptance among jurists of Mālik's opinion. And this is rightly so, because the achievement of $i j m \bar{a}^{*}$, in the way it is described by so many usüli methodologists, is not what the Shari'ah intends, nor can it reasonably be expected to come about in such a fashion. In my opinion, it is more accurate to say that $i j m \tilde{a}^{\prime}$ is nothing but a consultative legal decision offered by qualified jurists. This view is shared by Khallāf and confirmed by al Turābī. It is worthwhile to consider today the adoption of shūrā (consultative legal decisions adopted by jurists au-thorized to deal with legal matters) and to disregard the theory of $i j m \bar{a}^{\prime}$ in its old meaning. Thus the term becomes "the opinion of the jamáa $a h$ (the local Muslim community) and not ijmä:

Fourthly: What about ijtihad (independent reasoning)? I do not mean the controversy over whether to reopen the door of ijtihad or what restrictions apply to it. There is almost total agreement that ijtihad is a necessity required by the nature of civilizational development and growth. This is the nature of life, for what is incapable of development and growth is either dead or dying. The real problem is in the extent of ijtihad and its fundamental guidelines.

Ijtihad is important because it deals with the changes of "customs," according to al Shätibī's al Muwäfaqāt. What it refers to is the behavior 
of people in their daily activities. The author believes that "since the customs are different, every custom will be referred to a certain fundamental principle of the Shari'ah. Legal decisions are fixed, and they follow their reasons wherever they are without exceptions... It is a legal requirement that current customs be taken into account whether they were originally legal or illegal." He adds:

The basic consideration in customs is understanding their meanings for . . . if we find that the customs serve the masa âlih (interests) of the public and that the general rules and principles turn with them wherever they turn, one can see that a thing is prevented where there is no maslahah (interest) in it. If it has a maslahah, it is allowed. For example a dirham for a dirham for a certain period is forbidden in betting, but permitted in lending, and selling moist dates for dry dates is forbidden whenever it is done haphazardly or merely for the purpose of usury without any maslahah, while it will be allowed if the maslahah carries a greater weight ... then the laymen expanded in the area of reasons and merits to make legal decisions in the field of customs. The most reasoning that has been made in this field is that the appropriate custom is that which, if presented to the mind, will be accepted by it.

Mālik expanded on this subject to the point where he wrote of mașalih mursalah and measuring them by istihsān (preference) and saying that "it is nine-tenths of knowledge." To this, al Shātibī added:

If the outer appearance and inner facts of an action are legitimate, then there is no problem; and yet, if the outer appearance agrees and the masslahah disagrees, then the action is wrong and illegal, for legal actions are not sought for themselves; they are sought for other purposes and meanings, which are the masãlih for which they were made legal.

This meaning is unchallenged in all books dealing with ussūl. We present it here to remind people that standing by the text or abandoning ijtihad where there is textual support is not an absolute rule. Many modern questions need ijtihad and a pertinent text, for the text's literal meaning may not achieve the maslahah but may, in fact, disagree with it.

Most of the ijtihad that we need falls within the confines of qiyās mursal, for the situation of modern societies differs greatly from that faced by Muslim societies in the early stages of development. As a result 
of this reality, the kinds of mu'ämalät and the status of the public interests have changed. It is necessary to go back to the basic rule, which stipulates that the fundamental premise is that everything is allowed and that prohibition is not applied without a text (provided that the public interests are achieved). Then we look into new events and make ijtihad within the limits of the science of usül.

In conclusion, a Muslim researcher who wishes to write about any behavioral science from an Islamic point of view must follow a method that relies upon Islamic philosophy or the Shari 'ah, which is the ideal that determines the aim of life and the motive for every action. The "general theory" for the behavioral science in question must be derived from the Islamic ideal. At this point, the researcher will find that he/she is in disagreement with the substantive science, that he/she is dealing with the whole and not the part, and that modern relativity is included in the principle of mașlahah when resorting to qiyās, whether it be mursal or nonmursal.

Finally, it is inevitable that we go back to the science of ușül and rely on it when we try to establish a new methodology that combines the different types of scientific research in every behavioral science. 